\title{
高度肥満患者に対する婦人科腹腔鏡下手術の一例 A case report of gynecological laparoscopic surgery for the morbidly obese patient.
}

\author{
石川県立中央病院 産婦人科 \\ 吉成秀夫、干場 勉、齋藤里奈、石川博士、平吹信弥、佐々木博正、朝本明弘
}

\section{緒言}

肥満患者に対する開腹手術では、術後合併症の 発生頻度は非肥満患者の場合と比べ $2 \sim 5$ 倍高い との報告がある ${ }^{11}$ 。呼吸障害、血栓症などの術 後合併症予防には、早期離床が必要で、そのため には腹腔鏡下手術などの低侵襲手術が非常に有用 と思われる。しかし、特に高度肥満患者に対する 腹腔鏡下手術では、脂肪の過多により手術操作や 視野確保が非常に困難であるため、はじめから開 腹手術で行われる場合もある。Shen CCらの報告 によると、腹腔鏡補助下腟式子宮全摘術 (LAVH) において、Body Mass Index (BMI) 25以上の 肥満婦人では、その $21 \%$ が開腹術への変更を余儀 なくされたとしている2)。

そのため、高度肥満患者に対する腹腔鏡下手術 のためには肥満者用の対策が必要であるが、現在、 確立したものがなく、個々の症例にあわせて手技 や使用機器の工夫をしなければならない。

そこで今回、身長 $158 \mathrm{~cm}$ 、体重 $120 \mathrm{~kg} 、$ BMI48 の高度肥満婦人の卵巣腫瘍茎捻転に対し、腹腔鏡 下手術を施行したので報告する。

\section{症例}

39 歳 3 回経産。身長 $158 \mathrm{~cm}$ 、体重 $120 \mathrm{~kg}$ 、 BMI48。主訴は左下腹部痛。平成14年11月日夜、 突然左下腹部痛が出現し、近医を受診。CTにて 下腹部に径 $16 \mathrm{~cm}$ の腫瘍を認め、左卵巣腫瘍茥捻 転疑いのため、当院救急外来に紹介受診された。

来院時、顔面は苦悶様。腹部全体が膨隆し、左 下腹部に強い圧痛と自発痛を認めた。四 1 は前医 のCTで、骨盤部から臍上にかけて径 $16 \mathrm{~cm}$ の腫瘤 を認めた。
腫瘤の壁は薄く、表面は平滑、充実部分を持た ないことより良性腫瘍と考えられた。また、皮下 には厚さ $5 \mathrm{~cm}$ 以上の脂肪を認め、骨格が小さく 見えるほどの肥満状態だった（図 1 )。以上より、 左卵巣腫瘍茎捻転を疑い、緊急腹腔鏡下手術を施 行した。

\section{図 1 術前腹部CT}



肥満症例では、トロッカーの挿入、鉗子の可動 域、腫瘤の摘出、視野の確保に問題があるため、 今回はまず、恥骨上 $3 \mathrm{~cm}$ に $3 \mathrm{~cm}$ の縦切開を入れ、 そこよりラップディスクミニを設置し気腹、その 後臍部、左右側腹部よりトロッカーを挿入し手術 を行った（図 2 ）。気腹圧は $15 \mathrm{mmHg}$ で開始し、 その後 $8 \mathrm{mmHg}$ にた。

腹腔鏡所見にて暗赤色にうっ血し、720度捻転 している左卵巣腫瘍を認め（図 3 )、左卵单腫瘍 茎捻転と診断、腹腔鏡下左子宮附属器摘出術を行 った。麻酔は全身麻酔 (GOS)、手術時間は90分 で出血量は少量だった。

摘出標本の病理診断はserous cystadenoma。 内容物は淡黄色の漿液性の液体で、量は $2320 \mathrm{ml}$ だった。 


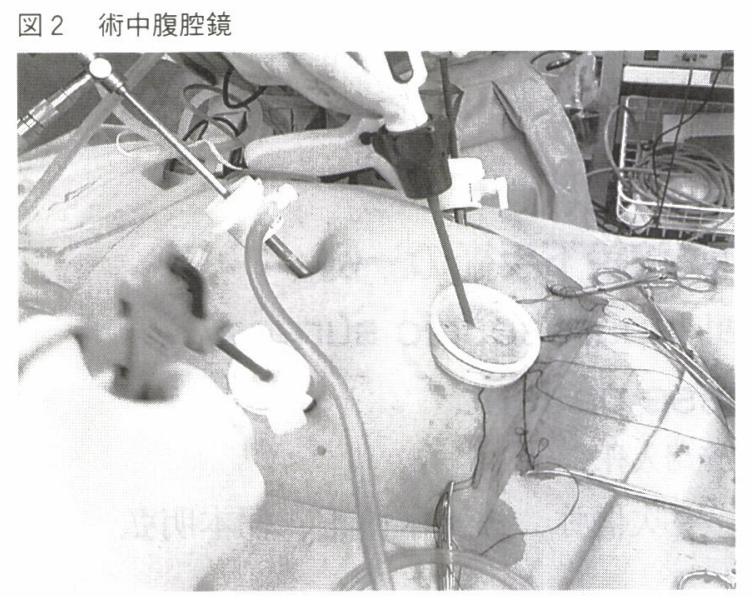

図 3 腹腔内所見

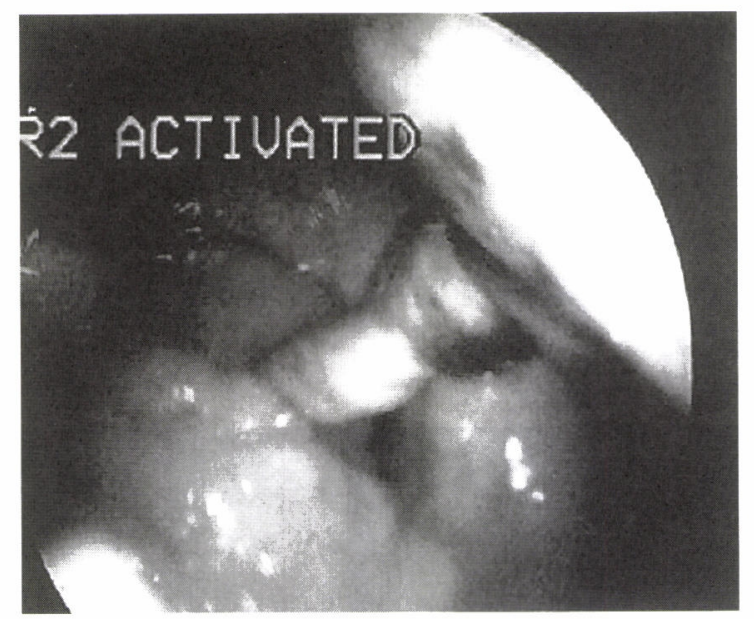

血栓症予防のため術前より弾性ストッキングを 着用、下肢のintermittent positive pressure、術 後36時間へパリンの点滴7500単位 日を行った。

術後経過は順調で、1 日目には食事を開始し、 尿道バルーンも抜去し、離床開始となった。創部 治癒も良好で、3 日目には抜鈎、4 日目にはシャ ワーも可能となった。この時点で退院が可能とな ったが、本人の希望により7 日目退院となった。

\section{考察}

今回、高度肥満婦人の卵巣腫瘍茥捻転に対し、 ラップディスクミニと気腹を用いた腹腔鏡下手術 を施行した。肥満腹腔鏡下手術の手技上の問題点 としては、トロッカーの挿入、鉗子の可動域、腫 瘤摘出、視野確保の問題が挙げられる ${ }^{1)}$ 。今回、 ラップディスクミニを使用したところ、トロッカ 一の挿入や可動域の問題は少なく、また、腫瘍も 容易に摘出できたため、非常に効果的であったと 思われた。また、本症例では腹腔内視野について は、気腹を行うことにより腸管蠕動の影響はほと んどなく、開腹と遜色ないぐらいの視野を確保す ることができた。
今回の症例については、腹腔鏡は用いずに、 mini laparotomyのみによる方法も考えられたが、 皮下脂肪が厚く、小さい切開では腹腔内操作や視 野確保が、腹腔鏡よりもさらに困難と予想された ため実施しなかった。

また、気腹法については、厚い腹壁を持ち上げ るための気腹圧による呼吸障害が懸念される 本症例では、はじめ気腹圧を $15 \mathrm{mmHg}$ で12分間 気腹した後、 $8 \mathrm{mmHg}$ にげ゙40分間行ったが、 術中のSpO2は98\%、PCO2は37mmHgのままで、 気腹による呼吸の影響はほとんど認められなかっ た。今回の症例では、高度肥満ではあったが、呼 吸循環器に異常がなかったこと、3 回経産婦で腹 壁の伸びが良く通常の気腹圧で手術が可能であつ たこと、気腹時間が短時間で済んだことが、呼吸 への影響がほとんどみられなかった要因と思われ た。

もう一つ気腹の問題点として深部静脈血栓症 （DVT）の危険性の増加がある。気腹による腹腔 内圧上昇により、腹部臓器、下肢の血流は低下し、 12〜 $14 \mathrm{mmHg}$ の気腹で、下肢の血流速度は30 40\%低下するといわ机ている3”。DVに対して何 の予防法もとらない場合、症状のないDVTは $55 \%$ に発生するとの報告もある

そこで今回は、血栓症予防のため術前より弾性 ストッキングを着用、下肢のintermittent positive pressure、術後のヘパリンの点滴、早期 離床で気腹による血栓症増加への対策をはかっ た。

本邦ではBMI30以上の高度肥満者は約 $2 \%$ あ り、白人の $20 \%$ 程と比較してはるかに少ない ${ }^{5}$ 。 頻度としては高くはないが、ひとたび高度肥満婦 人の婦人科手術症例に遭遇した場合、手術法の選 択に苦慮することが尒想される。今回、ラップデ イスクミニと気腹を用いた方法が有用であった が、今後さらなる機器や手技上の工夫、合併症へ の対策により、高度肥満例でも腹腔鏡下手術は試 みる価值がある術式と思われた。

\section{結語}

1) 今回、高度肥満婦人に対する腹腔鏡下手術症 例を経験し、ラップディスクミニと気腹を用 いた方法が有用と思われた

2 ) 高度肥満婦人における気腹下の腹腔鏡下手術 では、呼吸障害が懸念されるが、本症例のよ うに経産婦で、呼吸循環器に異常がなく、気 腹が短時間の場合、呼吸に及ぼす影響は少な 
いと思われた。

3 ）機器や手技上の工夫や合併症の対策をとるこ とにより、高度肥満例でも腹腔鏡下手術は試 みる価值がある術式と思われた。

本論文の要旨は、第43回日本産婦人科内視鏡学会 (京都)におおいて発表した。

\section{文献}

1）門田 守人：手術手技研究会記事 肥満者手術 の問題点とその工夫 その 2 . 手術 $54.12 、 1873$ $\sim 1884 、 2000$

2 ) Shen CC, et al. : Laparoscopic-assisted vaginaal hysterectomy in women of all weights and the effects of weight on complications. J Am Assoc Gynecol Laparosc. Nov;9(4):468-73、2002

3) 風間 富栄：産婦人科医に必要な麻酔の知識 7 . 腹腔鏡下手術の麻酔. 産科と婦人科 $47.4 、 473 \sim$ 478,2003

4) Patel MI, et al. : The incidence of deep vein thrombosis after laparoscopic chlescystectomy. Med J Aust 164: 652 656, 1996

5 ) 朝川 秀樹、德永 勝人：肥満の疫学：進行しつ つある日本人の肥満. ホルモンと臨床 51.4、31 $\sim 41,2003$ 